\title{
Utilization Software Sibelius Basic Vocals in Department of Sendratasik Universitas Negeri Padang
}

\author{
Delvia Mona ${ }^{1, *}$ Hengki Armez Hidayat ${ }^{1}$
}

\author{
${ }^{1}$ Faculty of Languages And Arts, Universitas Negeri Padang, 25131, Indonesia \\ ${ }^{*}$ Corresponding author. Email: delviamona@fbs.unp.co.id
}

\begin{abstract}
Basic Vocals is a compulsory subject listed in the curriculum of the Central Education Study Program. In the course of the lecture, a theory of how to sing with proper vocal techniques is given and musical accompaniment is needed. The large number of students who take these courses does not allow the practice of singing directly to the accompaniment of music, nor is it practiced once or twice. The practice must be repeated so that students really understand the proper and correct vocal techniques. In addition, the teacher must also be concerned about and check the truth of the students in applying the vocal technique practice. As a result, teachers run out of time in teaching and tire quickly. To overcome this, an alternative solution is needed by utilizing computer technology media with "Sibelius" software to help the practical learning process the singing. Sibelius is a software program that is specifically used to write musical notation in the form of block notation. Thus, piano accompaniment in a song written in the Sibelius program can be played to accompany the song. This research was conducted using quasi-experimental research, namely experimental research carried out in one group only called the experimental group without any groups Comparator or control group.
\end{abstract}

\section{Keywords: Utilization, Sibelius Software, Learning Media, Basic Vocals}

\section{INTRODUCTION}

Education is a learning in terms of knowledge or skills that is carried out from generation to creating planning and training. Learning is a teaching and learning process that occurs interactions between educators and students, carried out consciously to achieve certain goals of educational institutions (Zamroni, 2000: 29).

Trillling and Fadel (2009) state that 21st century learning is oriented towards a digital lifestyle, thinking tools, learning research and how knowledge works. All forms of skills and skills in the 21 st century and industrial era 4.0 must be integrated into the educational element. The application of technology in the learning process provides significant changes and provides solutions to obstacles in the learning process. This also happens in learning in the Basic Vocals course.

Basic Vocals is a compulsory subject listed in the Sendratasik Education Study Program curriculum which has three main interests, namely drama, music and dance. These three interests are required to take the basic vocals courses listed in the even semester course distribution. The 2020 school year students who take Basic Vocal courses are 150 students from 5 classes. In the course of the lecture, a theory of how to sing with vocal techniques is given.

In the singing practice material as the application of vocal technique theory, musical accompaniment is needed. The large number of students taking these courses does not allow the practice of singing directly to the accompaniment, to be practiced once or twice. Practice must be repeated so that students really understand. In addition, the teacher must also pay attention and check the truth of the students in applying the vocal technique practice. As a result, teachers run out of time in teaching and tire quickly.

To overcome this, an alternative solution is needed by utilizing computer technology media with "Sibelius" software to help the learning process of singing practice. Sibelius is a software program that is used specifically for writing musical notation in the form of block notation. Apart from that, block notation can also be written without typing but by playing the piano or guitar included in the program.

Thus, piano accompaniment notation in a song written with the "Sibelius" program can be played to accompany the song. In connection with these problems, it is 
interesting to research and study more deeply, in a study entitled "Use of Sibelius Software in Basic Vocal Learning in Sendratasik Education Study Program, Faculty of Language and Arts, Padang State University."

\section{METHOD}

The research location was conducted by the Department of Speech, Faculty of Language and Arts, State University of Padang, Padang City, West Sumatra. The population in this study were all students of the Class 2019 Sendratasik Education Study Program who took Basic Vocal Courses, the implementation time began in semester 3 of the 2019/2020 school year. Meanwhile, the sample of this study is one class from the entire population selected by purposive random.

In this study, the type used is quasi-experimental research, namely experimental research carried out in one group only called the experimental group without a comparison group or control group (Arikunto, 2006).

The research design used was one group pre-test-post test design, which is an experimental study that was carried out in one group which was randomly selected and did not test the stability and clarity of the group's condition before being given treatment

\section{RESULTS AND DISCUSSION}

Based on the opinion of Spreadbury (2011: 7), the field of information technology cannot be separated from the word software. According to Holmes (2002: 5) in its development, software for computer music is divided into three categories, namely notater, composer, and reader. Sibelius 7 is one of those applications used to write notation. Sibelius 7 also functions as composer software, but not as complete as other composer software. There are many advantages in Sibelius 7, such as smooth screens, virtual instruments, easy recording, and the easiest MIDI plug-in. Smooth screen (smooth display) Sibelius 7 is a perfect display provided by Sibelius so that users can write notes properly and precisely in their position. The process stages include; 1) choosing basic vocal teaching materials 2) using sibelius to make basic vocal music accompaniment, 3) testing basic vocal accompaniment using Sibelius software.

\section{Selection of Basic Vocal Teaching Materials}

The Basic Vowel course, as the name implies, is a practical course related to understanding and implementing the vocal processing process, vocal techniques, all of which are intended and aim to know how to produce and form correct and good sound.

On the one hand, an understanding of the vocal processing process and the skills to produce and shape the sound with the correct vocal technique, becomes one of the main lecture materials called procedures or steps to produce and form sounds. On the other hand, the result of its formation is that the sound that has been formed is used or functioned as a tool for reading musical notation, etude, and singing standard simple songs. Therefore, there are two materials or materials in the lecture process, first, the ability to produce and form sound, and second, the ability to read notations, etude, and sing songs.

In accordance with these objectives, this text discusses various materials related to the understanding of producing and forming sound, namely; first, the standard and commonly used vocal breathing technique, namely the diaphragmatic breathing technique. Therefore, for various reasons and considerations, in this text, there is no discussion of other breathing techniques such as shoulder, chest and abdominal breathing techniques, both theoretical and exercise procedures which of course can be used as a comparison with diaphragmatic breathing. But again it is the diaphragmatic breathing technique that is discussed here.
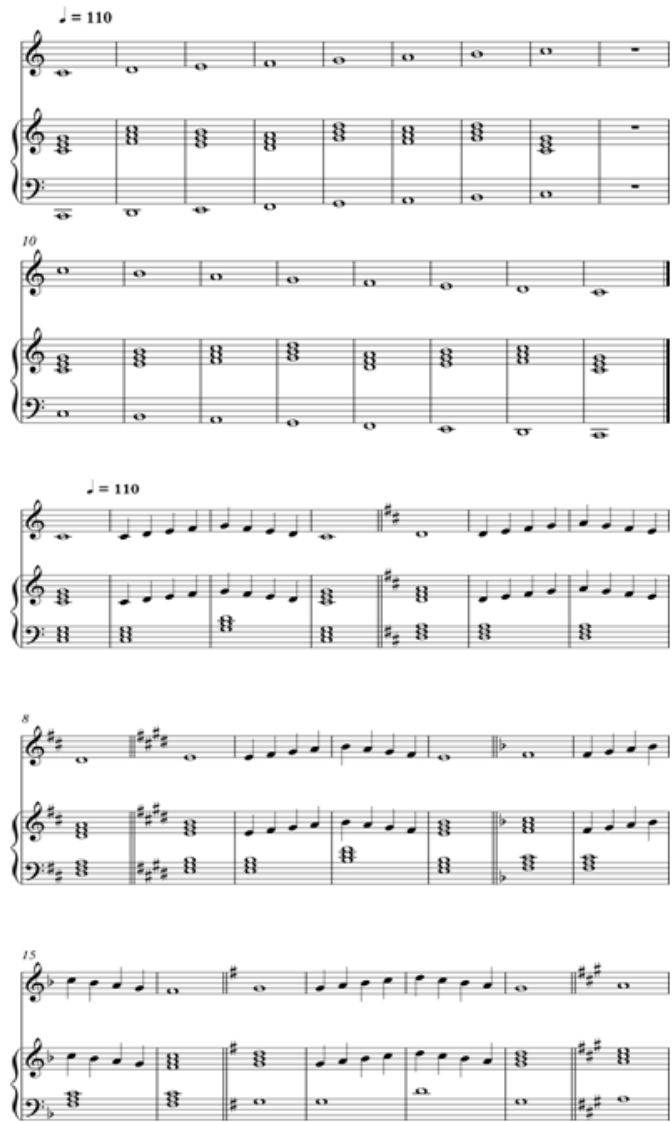


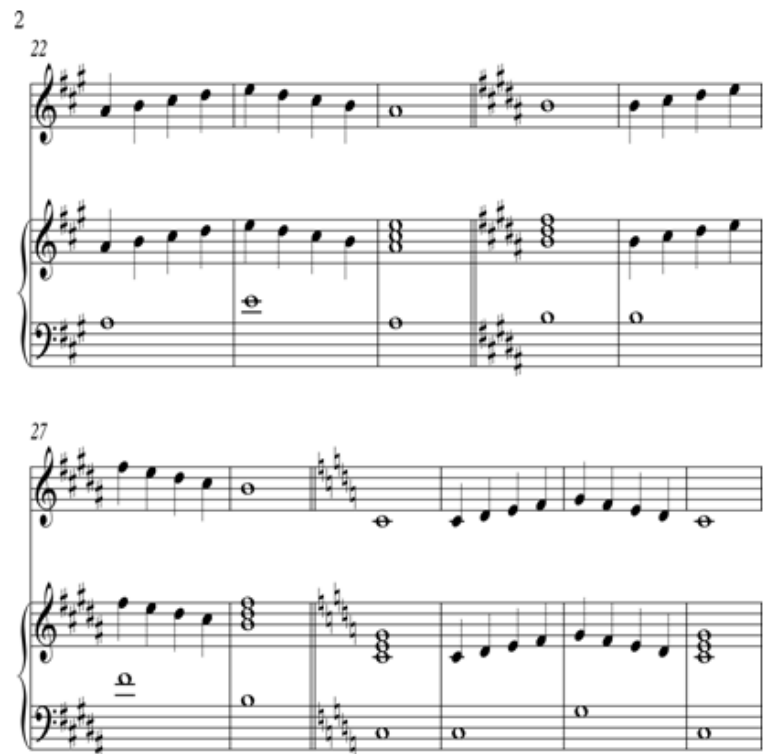

The second material is related to the basic techniques of producing and forming sound, including vocal resonance space, singing posture, controlling the tongue in producing sound.
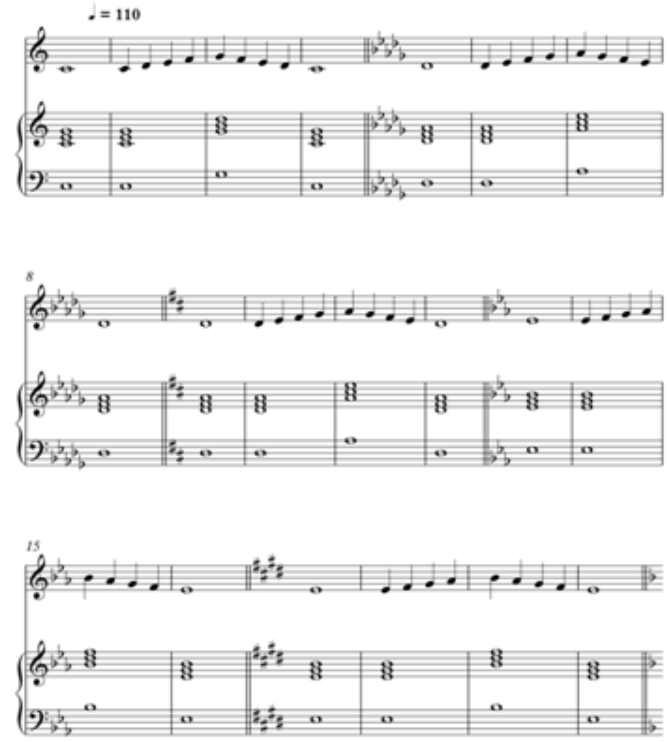
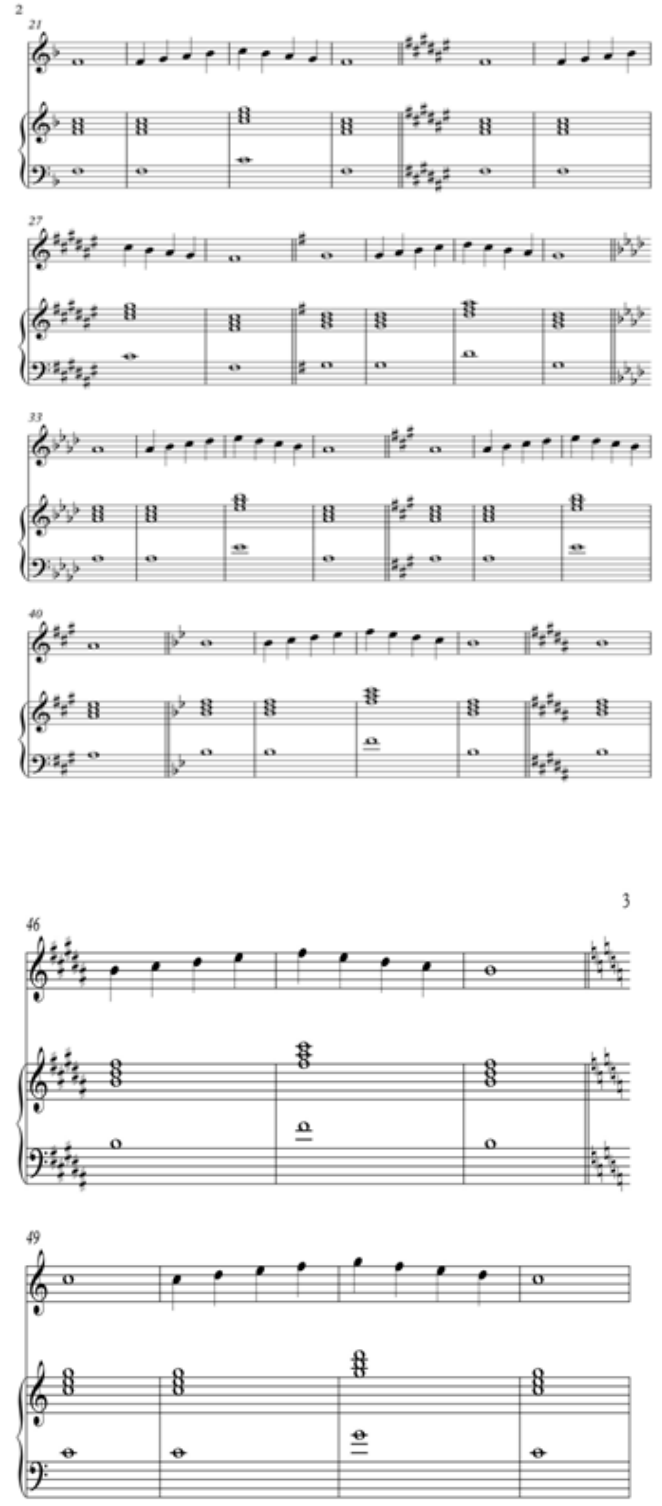

Based on all the material discussed, namely the understanding and ability to produce sound, which is based on correct and good basic techniques, it is possible to develop it properly and well by students in the wider community after leaving college or after becoming a bachelor of music education.

The teaching and learning process of this basic vocal practice, of course, uses various methods for each objective or competency such as lectures, discussions, demonstrations, demonstrations, imitation, and drills. Because the material of knowledge and insight, for example tenju, is delivered through the lecture method, and then discussed with students, in order to obtain a clear understanding and then it can be practiced properly and well. Likewise with the material related to the skills of producing and shaping sound, it requires demonstration, 
demonstration, imitation methods, and then reinforced by the drill method.

\section{Sibelius software to create basic vocal accompaniment notations}

Based on the opinion of Spreadbury (2011: 7), the field of information technology cannot be separated from the word software. According to Holmes (2002: 5) in its development, software for computer music is divided into three categories, namely notater, composer, and reader. Sibelius 7 is one of those applications used to write notation. Sibelius 7 also functions as composer software, but not as complete as other composer software. There are many advantages in Sibelius 7, such as smooth screens, virtual instruments, easy recording, and the easiest MIDI plug-in.

Smooth screen (smooth display) Sibelius 7 is a perfect display provided by Sibelius so that users can write notes properly and precisely in their position. Simple display of Sibelius 7, adapted to the computer used to run Sibelius 7. Sibelius 7 is a notater software that is easier to operate than other software. Sibelius always releases various new versions with features tailored to the OS model being used by the user. Sibelius 7 has excellent notation display quality and virtual instrument sound quality.

The operating standards for Sibelius 7 are adapted to the windows operating system being used, making it easier for users to find options for assistance to be used. Virtual instruments sound is one of the advantages of Sibelius 7 . The actual sound of the instrument is recorded directly against the designated music players, and then processed using a synthesizer. Even though it is processed using a synthesizer, Sibelius 7 does not remove the real sound element from the instrument.

So, the user can listen to the sound results of the written notes on the selected instrument, and sound like he is listening to the instrument in front of him. Based on the explanation of this theory, it can be concluded that Sibelius 7 can be used as a musical accompaniment for the Basic Vocal course, because of the perfect appearance and sound of the instruments. The clarity of the delivery of messages in the form of views and sounds can improve understanding of the notation.

\section{Testing Basic Vocal Accompaniment Using The Sibelius} Software.

The Trial Phase is an important stage in the Basic Vocal Practice process using vocal accompaniment music and learning basic vocals. Before entering this stage, the teaching material must be ascertained first. The trial stage of this basic vocal accompaniment music is described with the result of vocal music accompaniment notation.

TANAH AIRKU (My Own Land)

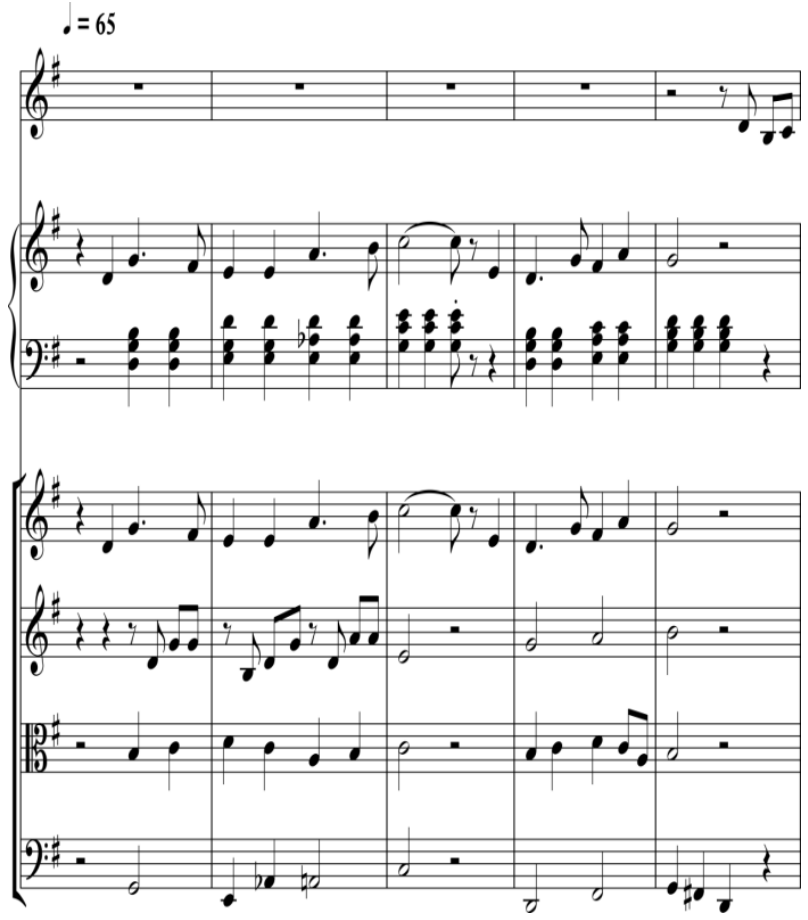

2

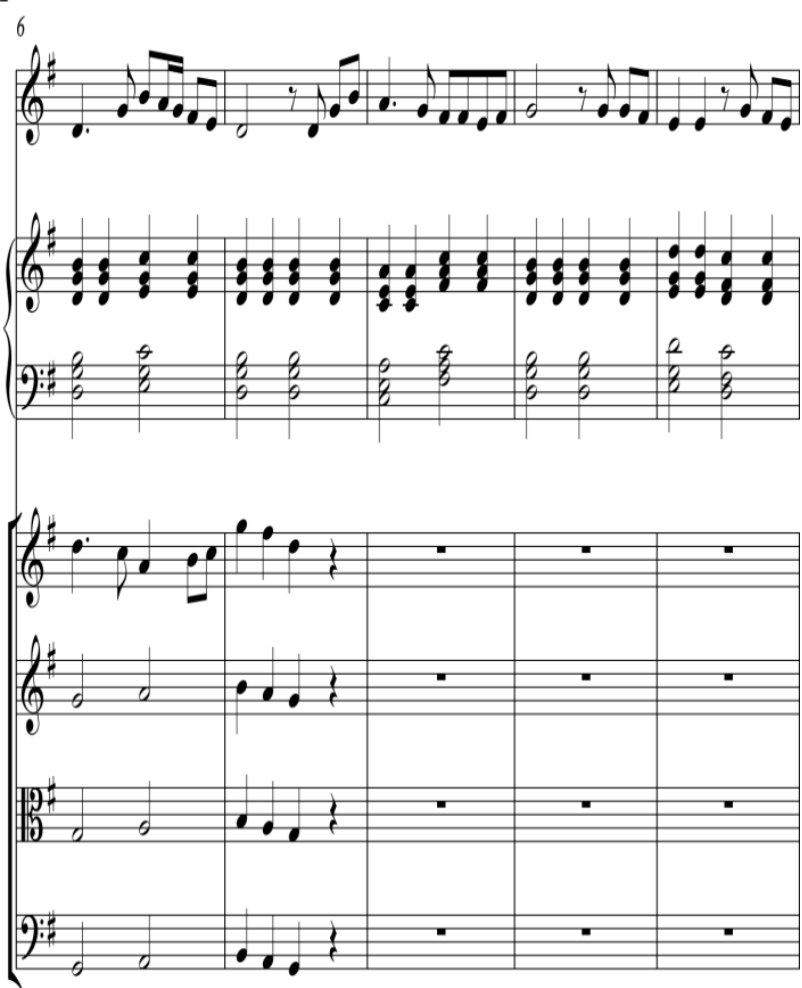



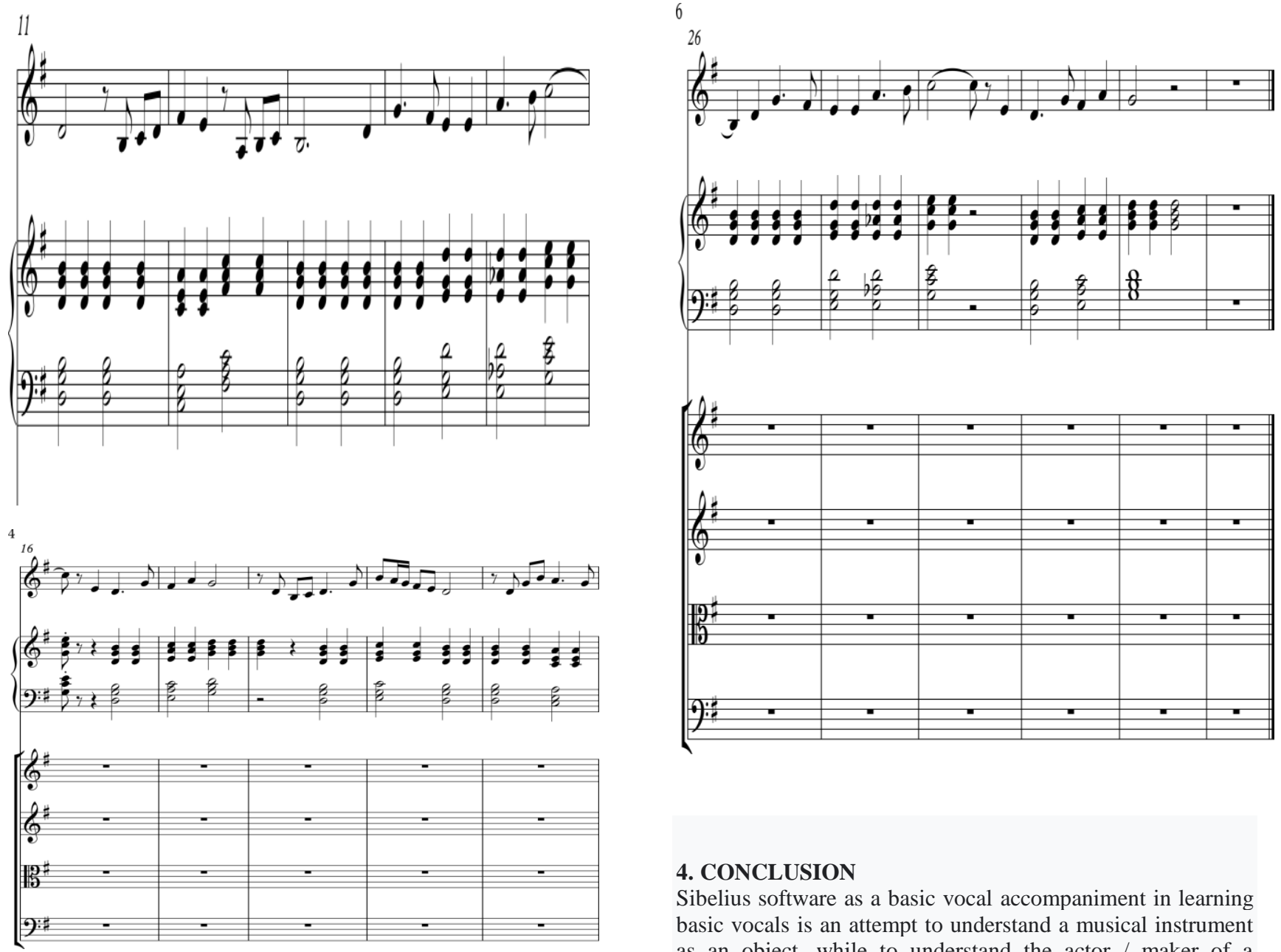

\section{CONCLUSION}

Sibelius software as a basic vocal accompaniment in learning basic vocals is an attempt to understand a musical instrument as an object, while to understand the actor / maker of a musical instrument is an attempt to motivate the actor himself. Because on the one hand the substance is to fulfill the necessities of life, on the other hand, essentially as an object, it becomes central to knowing other sides that make its presence beneficial to society, both academically, economically and practically.

\section{REFERENCES}

[1] Zamroni. 2000. Paradigma Pendidikan Masa Depan. Yogyakarta: Bigraf Publishing.

[2] Trilling and Fadel. 2009. 21st century skills: learning for life in our times. Jossey Bass: USA

[3] Arikunto, Suharsimi. 2006. Prosedur Penelitian Suatu Pendekatan Praktik. Jakarta: Rineka Cipta.

[4] Spreadbury, D., Ben \& Finn, J. (2011). Sibelius 7: Reference Guide. USA: Avid Technology, Inc.

[5] Holmes, Thomp. (2002). Electronic and Experimental Musik and Culture. New York: Routledge. 